\title{
Oxidative stress is induced by islet amyloid formation and time-dependently mediates amyloid-induced beta cell apoptosis
}

\author{
S. Zraika • R. L. Hull • J. Udayasankar • \\ K. Aston-Mourney • S. L. Subramanian • \\ R. Kisilevsky • W. A. Szarek • S. E. Kahn
}

Received: 10 July 2008 / Accepted: 12 December 2008 / Published online: 16 January 2009

(C) Springer-Verlag 2009

\begin{abstract}
Aims/hypothesis Islet amyloid in type 2 diabetes contributes to loss of beta cell mass and function. Since islets are susceptible to oxidative stress-induced toxicity, we sought to determine whether islet amyloid formation is associated with induction of oxidative stress.

Methods Human islet amyloid polypeptide transgenic and non-transgenic mouse islets were cultured for 48 or $144 \mathrm{~h}$ with or without the antioxidant $N$-acetyl-L-cysteine (NAC) or the amyloid inhibitor Congo Red. Amyloid deposition, reactive oxygen species (ROS) production, beta cell apoptosis, and insulin secretion, content and mRNA were measured.

Results After 48 h, amyloid deposition was associated with increased ROS levels and increased beta cell apoptosis, but no change in insulin secretion, content or mRNA levels. Antioxidant treatment prevented the rise in ROS, but did not prevent amyloid formation or beta cell apoptosis. In contrast, inhibition of amyloid formation prevented the induction of oxidative stress and beta cell apoptosis. After
\end{abstract}

S. Zraika $(\bowtie) \cdot$ R. L. Hull · J. Udayasankar · K. Aston-Mourney •

S. L. Subramanian $\cdot$ S. E. Kahn

Division of Metabolism, Endocrinology and Nutrition,

Department of Medicine, University of Washington and VA Puget

Sound Health Care System,

1660 South Columbian Way (151),

Seattle, WA 98108, USA

e-mail: zraikas@u.washington.edu

R. Kisilevsky

Department of Pathology and Molecular Medicine and

Department of Biochemistry, Queen's University,

Kingston, ON, Canada

W. A. Szarek

Department of Chemistry, Queen's University,

Kingston, ON, Canada
$144 \mathrm{~h}$, amyloid deposition was further increased and was associated with increased ROS levels, increased beta cell apoptosis and decreased insulin content. At this time-point, antioxidant treatment and inhibition of amyloid formation were effective in reducing ROS levels, amyloid formation and beta cell apoptosis. Inhibition of amyloid formation also increased insulin content.

Conclusions/interpretation Islet amyloid formation induces oxidative stress, which in the short term does not mediate beta cell apoptosis, but in the longer term may feed back to further exacerbate amyloid formation and contribute to beta cell apoptosis.

Keywords Beta cell apoptosis · IAPP - Insulin secretion · Islet amyloid · Oxidative stress
Abbreviations
IAPP Islet amyloid polypeptide
NAC $\quad N$-acetyl-L-cysteine
ROS Reactive oxygen species
WAS-406 2-Acetamido-1,3,6-tri- $O$-acetyl-2,4-dideoxy-
$\alpha$-D-xylohexopyranose

\section{Introduction}

Islet amyloid deposits are a characteristic morphological feature of the pancreas in type 2 diabetes, comprising fibrils formed from islet amyloid polypeptide (IAPP) [1, 2]. Factors affecting the amyloidogenicity of IAPP include, in addition to a permissive environment, species-specific differences in the amino acid sequence. Specifically, human but not rodent IAPP is capable of forming amyloid fibrils [3-5]. Amyloid deposition from human IAPP has been 
shown to be more frequent in the typical type 2 diabetes milieu of chronically elevated glucose and NEFAs [6-10].

Many studies have demonstrated that islet amyloid formation is cytotoxic [11-14], with some evidence that IAPP oligomers may be the toxic species [13, 15-18]. Examination of autopsy pancreas specimens from patients with type 2 diabetes has suggested a positive relationship between the amount of islet amyloid and beta cell loss [1921]. In addition, there is growing support for involvement of oxidative stress in islet dysfunction and death. Typically, the generation of damaging reactive oxygen species (ROS) during oxidative stress has been strongly linked to defective insulin gene expression, reduced insulin content and impaired insulin secretion, as reviewed [22]. Further, in autopsy tissue from Japanese patients with type 2 diabetes, islets that contained amyloid also stained positive for oxidative stress markers [23]. In other studies, treatment of immortalised beta cells with exogenous human IAPP resulted in intracellular ROS accumulation [24] and lipid peroxidation [25]. Also, antioxidant treatment inhibited the progression of human IAPP-induced apoptosis [24].

While the data linking human IAPP-induced toxicity to oxidative stress are intriguing, all the work has been performed using autopsy samples that enable only a retrospective evaluation [23] or by applying exogenous human IAPP to immortalised cells [24-26], which in some studies $[27,28]$ were not pancreatic beta cells. These approaches limit the ability to reach a definitive conclusion about whether oxidative stress is a cause or effect of islet amyloid formation, which in humans is derived from endogenous IAPP. Thus, in the present study, we employed an in vitro model using isolated islets from our human IAPP transgenic mice [10] to investigate the link between islet amyloid formation and oxidative stress, and the consequences for beta cell function and survival.

\section{Methods}

Transgenic mice Hemizygous transgenic mice with beta cell production of human IAPP [29] on an F1 C57BL/6× DBA/2J background were used in this study. Non-transgenic littermates were used as controls. Transgenic status was determined by polymerase chain reaction, as previously described [30]. Mice were fed a diet containing $18 \%$ energy from fat ( $9 \%$ fat by weight; Purina 5021; Purina, Richmond, IN, USA) or 45\% energy from fat (D12290; Research Diets, New Brunswick, NJ, USA). The study was approved by the Institutional Animal Care and Use Committee at the VA Puget Sound Health Care System.

Immunohistochemistry for nitrotyrosine Paraffin pancreas sections $(5 \mu \mathrm{m})$ were cut from three non-transgenic and three human IAPP transgenic mice after 12 months of highfat $(45 \%)$ feeding [9]. Sections were treated with $0.05 \%$ (vol./vol.) trypsin for antigen retrieval and non-specific immunoreactivity was blocked with $10 \%$ (vol./vol.) normal goat serum. Sections were reacted overnight with mouse monoclonal anti-nitrotyrosine antibody (1:100; Chemicon International, Temecula, CA, USA), followed by goat antimouse Cy3 (1:250) and thioflavin S staining to visualise amyloid deposits. To visualise cell nuclei, sections were counterstained with Hoechst $33258(2 \mu \mathrm{g} / \mathrm{ml})$. An average of 18 islets per mouse were examined. For negative controls, the primary antibody was omitted.

Isolation and culture of pancreatic islets Islets were isolated from the pancreases of 10-week old female and male mice by collagenase digestion using methods previously described [31]. Islets were cultured overnight in RPMI-1640 medium (containing $11.1 \mathrm{mmol} / 1$ glucose), in a $37^{\circ} \mathrm{C}$ humidified atmosphere of $95 \%$ air:5\% $\mathrm{CO}_{2}$ to allow them to recover from the isolation procedure. Islets were then either collected for measurements described below or transferred to media containing either $5.5 \mathrm{mmol} / 1$ or $16.7 \mathrm{mmol} / 1$ glucose and cultured for an additional 48 or $144 \mathrm{~h}$ in the absence or presence of the antioxidant $\mathrm{N}$ acetyl-1-cysteine (NAC) $(5 \mathrm{mmol} / \mathrm{l})$ or one of two amyloid inhibitors: 2 -acetamido-1,3,6-tri- $O$-acetyl-2,4-dideoxy- $\alpha$-Dxylohexopyranose (WAS-406; $100 \mu \mathrm{mol} / \mathrm{l}$ ) or Congo Red $(200 \mu \mathrm{mol} / \mathrm{l})$. WAS-406 [32, 33] and Congo Red [34, 35] have previously been shown to inhibit IAPP oligomer and/ or amyloid formation. The choice of dose for each amyloid inhibitor was based on dose-response experiments that we have performed in this model [32] (S. Zraika, unpublished observations). The culture periods were based on our previous studies demonstrating amyloid visible by light microscopy at $48 \mathrm{~h}$ and enhanced levels after $144 \mathrm{~h}$ in $16.7 \mathrm{mmol} / \mathrm{l}$ glucose culture [10].

Measurement of ROS production ROS production was measured in islets following overnight recovery or after 48 or $144 \mathrm{~h}$ culture as previously described [36] with minor modifications. Briefly, 70 islets were dispersed by treatment with $0.0075 \%$ (vol./vol.) trypsin and then cells were loaded with $100 \mu \mathrm{mol} / 1$ oxidant-sensitive fluorescent carboxy$\mathrm{H}_{2}$ DCFDA dye (Invitrogen, Carlsbad, CA, USA) for $30 \mathrm{~min}$. After washing with phosphate-buffered saline, cells were resuspended in islet culture medium without phenol red, transferred to a 96 -well plate and incubated at $37^{\circ} \mathrm{C}$ for $2 \mathrm{~h}$. For a positive control, a parallel sample of dispersed cells from 70 islets was treated with $100 \mu \mathrm{mol} / 1$ hydrogen peroxide for $2 \mathrm{~h}$. ROS levels were measured by quantifying the fluorescence intensity in each well at an excitation wavelength of $485 \mathrm{~nm}$ and an emission wavelength of $530 \mathrm{~nm}$. 
Histological assessment of islet amyloid and beta cell apoptosis Islets were fixed in $4 \%$ (wt/vol.) phosphatebuffered paraformaldehyde and embedded in paraffin [10]. Sections $(5 \mu \mathrm{m})$ were cut and stained with thioflavin $\mathrm{S}$ to visualise amyloid deposits. For quantification of beta cell apoptosis, sections were stained with propidium iodide and anti-insulin antibody as previously described [37]. Histological assessments of amyloid and apoptosis were made in a blinded manner on an average of 19 islets per culture condition per experiment. Amyloid prevalence (\% of islets containing amyloid) and severity ( $\%$ of islet area occupied by amyloid) were determined using a computer-based quantitative method as reported previously [38], with islet area being determined morphometrically by manually outlining each islet when viewed under fluorescence at excitation $480 \mathrm{~nm}$ and emission $505 \mathrm{~nm}$ (channel used for thioflavin $\mathrm{S}$ staining). The proportion of apoptotic beta cells was determined by manual counting of condensed and fragmented nuclei in insulin-positive cells.

Assessment of ${ }^{51} \mathrm{Cr}$ release Release of ${ }^{51} \mathrm{Cr}$ was used to assess cell viability after $48 \mathrm{~h}$ culture of islets in 5.5 or $16.7 \mathrm{mmol} / 1$ glucose [31]. This method is based on the principle that over $48 \mathrm{~h}$, viable cells retain preloaded ${ }^{51} \mathrm{Cr}$ intracellularly because cell membranes are intact. In contrast, non-viable cells develop leaky membranes and thus release preloaded ${ }^{51} \mathrm{Cr}$ into the media. Data were expressed as fractional ${ }^{51} \mathrm{Cr}$ release in terms of total incorporation (cpm in medium $/[\mathrm{cpm}$ in medium $+\mathrm{cpm}$ in islets $] \times 100$ ).

Evaluation of insulin secretion and content Following $48 \mathrm{~h}$ culture, insulin secretion was measured by islet perifusion as previously described [10]. Effluent fractions were collected at 2 to $5 \mathrm{~min}$ intervals during perifusion with $1.67 \mathrm{mmol} / \mathrm{l}$ glucose for $8 \mathrm{~min}$ (basal), then with $16.7 \mathrm{mmol} / 1$ glucose for $30 \mathrm{~min}$ (glucose-stimulated). Following $144 \mathrm{~h}$ culture, insulin secretion was measured in static incubations as previously described [31]. Supernatant fractions were collected after $60 \mathrm{~min}$ incubation of islets in either $2.8 \mathrm{mmol} / \mathrm{l}$ (basal) or $20 \mathrm{mmol} / 1$ (glucosestimulated) glucose. Samples were stored at $-20^{\circ} \mathrm{C}$ before determination of insulin by radioimmunoassay [30]. Islet insulin content was measured after acid-ethanol extraction.

Real-time quantitative RT-PCR Gene expression of insulin in isolated islets was determined with real-time quantitative RT-PCR performed using the TaqMan system (ABI Prism 7000; Applied Biosystems, Foster City, CA, USA) as previously described [39]. TaqMan Assays on Demand insulin II gene expression mix was from Applied Biosystems (Mm00731595_gH). TaqMan eukaryotic 18S rRNA (Hs99999901_s1; Applied Biosystems) was used as endogenous control. Each sample was run in triplicate.
Statistical analyses Data are presented as mean \pm SEM for the number of experiments indicated. Statistical significance was determined using analysis of variance or Mann-Whitney $U$ tests where appropriate, with nonparametric tests being used where data were not normally distributed. A $p$ value of $<0.05$ was considered statistically significant.

\section{Results}

Detection of oxidative stress markers in vivo To determine whether oxidative stress occurs in association with amyloid formation in vivo, pancreas sections from year-old, high fat-fed non-transgenic and human IAPP transgenic mice [9] were stained for nitrotyrosine, a widely used marker of oxidative stress [36, 40, 41]. Amyloid formation and nitrotyrosine immunoreactivity were only observed in human IAPP transgenic islets (Fig. 1a).

Analysis of islets after isolation, overnight recovery and prior to treatment Once the presence of oxidative stress markers in vivo had been demonstrated, an in vitro culture model was then adopted to directly examine the relationship between amyloid formation and oxidative stress. To ensure human IAPP transgenic islets did not differ from non-transgenic islets prior to culture, ROS levels, amyloid deposition, beta cell apoptosis and insulin content were determined following overnight recovery of isolated islets. Human IAPP transgenic and non-transgenic islets had comparable ROS levels, beta cell apoptosis rates and insulin content. As expected, amyloid was not detected in any of the non-transgenic or human IAPP transgenic islets examined (Table 1).

Islet amyloid and ROS levels post $48 \mathrm{~h}$ culture in 5.5 and $16.7 \mathrm{mmol} / \mathrm{l}$ glucose Figure 1b,c shows representative thioflavin $\mathrm{S}$ staining of islet amyloid in non-transgenic and human IAPP transgenic islets cultured for $48 \mathrm{~h}$ in $5.5 \mathrm{mmol} / 1$ or $16.7 \mathrm{mmol} / 1$ glucose. Islet amyloid was present only in human IAPP transgenic islets cultured in $16.7 \mathrm{mmol} / \mathrm{l}$ glucose (Fig. 1c). After $48 \mathrm{~h}$, ROS levels were comparable in non-transgenic and human IAPP transgenic islets cultured in $5.5 \mathrm{mmol} / \mathrm{l}$ glucose and in non-transgenic islets cultured in $16.7 \mathrm{mmol} / \mathrm{l}$ glucose (Fig. 1d). In contrast, human IAPP transgenic islets cultured in $16.7 \mathrm{mmol} / 1$ glucose for $48 \mathrm{~h}$ had significantly elevated ROS levels compared with those cultured in $5.5 \mathrm{mmol} / 1$ glucose and with non-transgenic islets cultured at $16.7 \mathrm{mmol} / 1$ glucose.

Islet amyloid and ROS levels after $48 \mathrm{~h}$ antioxidant treatment To investigate whether reducing ROS levels over 
a

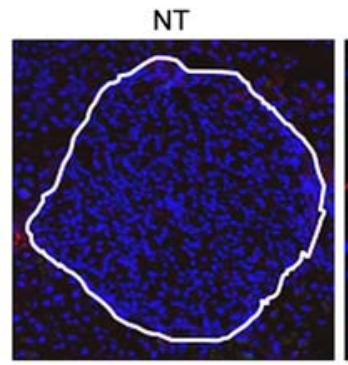

b



C


d

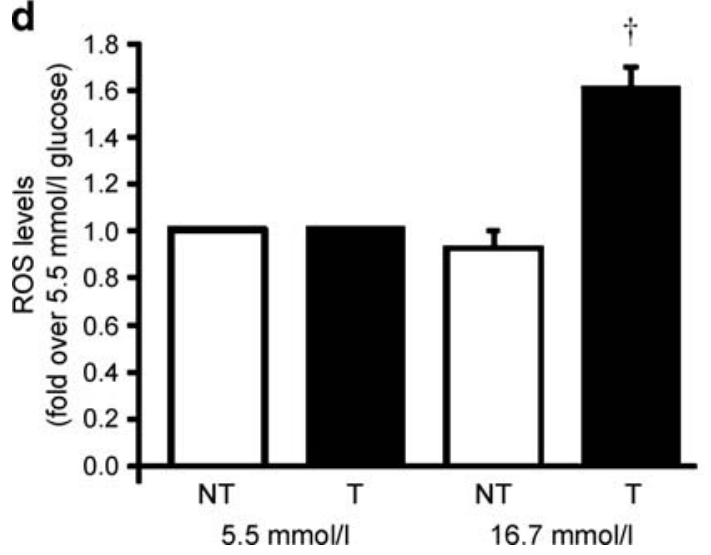

Fig. 1 a Representative islets from pancreases of non-transgenic (NT) and human IAPP transgenic (T) mice after 12 months on a high-fat diet. Nitrotyrosine (red) and amyloid (green) staining is seen in human IAPP transgenic islets only. Representative islets from non-transgenic and human IAPP transgenic mice following $48 \mathrm{~h}$ culture in $5.5 \mathrm{mmol} / \mathrm{l}$ (b) or $16.7 \mathrm{mmol} / \mathrm{l}$ (c) glucose. Only human IAPP transgenic islets cultured in $16.7 \mathrm{mmol} / \mathrm{l}$ glucose developed amyloid deposits (arrows). Red, insulin; blue, nuclei; green, amyloid. d ROS levels in non-transgenic and human IAPP transgenic islets following $48 \mathrm{~h}$ culture in $5.5 \mathrm{mmol} / \mathrm{l}$ or $16.7 \mathrm{mmol} / \mathrm{l}$ glucose. Data are expressed relative to the fluorescence from $5.5 \mathrm{mmol} / 1$ glucose-cultured islets. Only human IAPP transgenic islets cultured in $16.7 \mathrm{mmol} / \mathrm{l}$ glucose had significantly elevated ROS levels. $n=11 ;{ }^{\dagger} p<0.0005$ vs NT $16.7 \mathrm{mmol} / 1$ glucose
$48 \mathrm{~h}$ could prevent islet amyloid formation, islets were cocultured with the antioxidant NAC. NAC significantly decreased ROS levels in non-transgenic and human IAPP transgenic islets cultured in $5.5 \mathrm{mmol} / 1$ or $16.7 \mathrm{mmol} / \mathrm{l}$ glucose when compared with those cultured at either glucose concentration alone (Fig. 2a).

Human IAPP transgenic islets cultured in $16.7 \mathrm{mmol} / \mathrm{l}$ glucose developed islet amyloid with a prevalence of $52 \pm 4 \%$ (Fig. 2b) and severity of $0.53 \pm 0.17 \%$ (Fig. 2c). Treatment with NAC did not alter amyloid prevalence (Fig. 2b) or severity (Fig. 2c), suggesting amyloid formation occurs upstream or independently of increased ROS production. As anticipated, islet amyloid was not present in non-transgenic islets or in human IAPP transgenic islets cultured in $5.5 \mathrm{mmol} / \mathrm{l}$ glucose (data not shown).

Islet amyloid and ROS levels after $48 \mathrm{~h}$ treatment with amyloid inhibitors To test the hypothesis that islet amyloid formation results in increased ROS levels, we co-cultured islets with one of two amyloid inhibitors (WAS-406 or Congo Red), then measured ROS levels. WAS-406 treatment of human IAPP transgenic islets cultured in $16.7 \mathrm{mmol} / 1$ glucose for $48 \mathrm{~h}$ significantly decreased amyloid prevalence (Fig. 3a) from $43.9 \pm 4.8$ to $27.2 \pm$ $4.4 \%$ ( $p=0.015)$. Similarly, Congo Red treatment decreased amyloid prevalence to $16.1 \pm 3.9 \% \quad(p=0.016)$. Amyloid severity in human IAPP transgenic islets cultured in $16.7 \mathrm{mmol} / \mathrm{l}$ glucose for $48 \mathrm{~h}$ was decreased from $0.76 \pm$ 0.13 to $0.13 \pm 0.03 \%(p=0.0004)$ and $0.02 \pm 0.01 \%(p=0.01)$ following WAS-406 and Congo Red treatment, respectively (Fig. 3b). Both WAS-406 and Congo Red prevented the increase of ROS levels in human IAPP transgenic islets cultured in $16.7 \mathrm{mmol} / 1$ glucose, while having no effect in non-transgenic islets or human IAPP transgenic islets cultured in $5.5 \mathrm{mmol} / 1$ glucose (Fig. 3c).

Release of ${ }^{51} \mathrm{Cr}$ after $48 \mathrm{~h}$ treatment with Congo Red or $N A C$ We next investigated whether amyloid formation and subsequent induction of oxidative stress is associated with reduced cell viability in human IAPP transgenic islets. Figure $4 \mathrm{a}, \mathrm{b}$ demonstrates that ${ }^{51} \mathrm{Cr}$ release did not differ between non-transgenic and human IAPP transgenic islets cultured in $5.5 \mathrm{mmol} / 1$ glucose for $48 \mathrm{~h}$. When cultured in $16.7 \mathrm{mmol} / \mathrm{l}$ glucose, both islet groups released significantly more ${ }^{51} \mathrm{Cr}$ than at $5.5 \mathrm{mmol} / \mathrm{l}$ glucose, indicating a decrease in cell viability. However, at the higher glucose concentration, human IAPP transgenic islets released significantly more ${ }^{51} \mathrm{Cr}$ than non-transgenic islets, demonstrating a further reduction in human IAPP transgenic islet cell viability.

To inhibit amyloid formation in this series of experiments, Congo Red was used. ${ }^{51} \mathrm{Cr}$ release from human IAPP transgenic islets cultured in $16.7 \mathrm{mmol} / \mathrm{l}$ glucose plus 
Table 1 ROS levels, beta cell apoptosis, insulin content and amyloid prevalence in islets following isolation and overnight recovery

\begin{tabular}{llll}
\hline Variable & $n$ & Non-transgenic & Human IAPP transgenic \\
\hline ROS levels (fold over non-transgenic) & 3 & 1.00 & $1.01 \pm 0.01$ \\
Apoptotic beta cells (\%) & 5 & $0.13 \pm 0.01$ & $0.10 \pm 0.05$ \\
Insulin content (nmol/100 islets) & 5 & $1,171 \pm 165$ & $1,347 \pm 266$ \\
Amyloid prevalence (\% islets with amyloid) & 5 & 0 & 0 \\
\hline
\end{tabular}

Values are shown as mean \pm SEM

Congo Red decreased significantly compared with that from human IAPP transgenic and non-transgenic islets in $16.7 \mathrm{mmol} / 1$ glucose. ${ }^{51} \mathrm{Cr}$ release from non-transgenic islets and islets cultured in $5.5 \mathrm{mmol} / \mathrm{l}$ glucose was unchanged in the presence vs the absence of Congo Red (Fig. 4a).

To determine whether ROS could mediate the amyloidinduced reduction in cell viability, islets were treated with NAC. ${ }^{51} \mathrm{Cr}$ release from both human IAPP transgenic and non-transgenic islets cultured in $16.7 \mathrm{mmol} / 1$ glucose plus NAC decreased significantly compared with that from islets in $16.7 \mathrm{mmol} / 1$ glucose alone. NAC did not change ${ }^{51} \mathrm{Cr}$ release from islets cultured in $5.5 \mathrm{mmol} / 1$ glucose (Fig. 4b).

\section{Beta cell apoptosis after $48 \mathrm{~h}$ treatment with Congo Red or} $N A C$ To determine whether amyloid-containing islets demonstrated increased beta cell apoptosis, we determined the proportion of condensed or fragmented nuclei in insulinpositive cells following $48 \mathrm{~h}$ culture. Beta cell apoptosis did

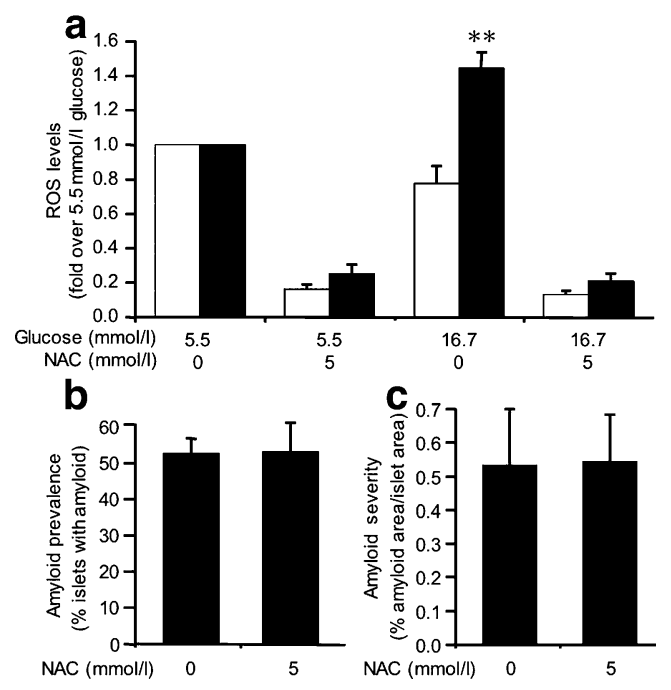

Fig. 2 a ROS levels in non-transgenic (white bars) and human IAPP transgenic (black bars) islets following $48 \mathrm{~h}$ culture in 5.5 or $16.7 \mathrm{mmol} / 1$ glucose with or without the antioxidant, NAC $(5 \mathrm{mmol} / \mathrm{l})$. Data are expressed relative to the fluorescence from $5.5 \mathrm{mmol} / 1$ glucose-cultured islets. NAC significantly decreased ROS levels in all islets, regardless of genotype or media glucose concentration. $n=3$; **p<0.01 vs nontransgenic. Amyloid prevalence (b) and severity (c) in human IAPP transgenic islets following $48 \mathrm{~h}$ culture in $16.7 \mathrm{mmol} / \mathrm{l}$ glucose with or without $5 \mathrm{mmol} / \mathrm{l}$ NAC. NAC treatment had no effect on amyloid prevalence or severity. $n=5$ not differ between non-transgenic and human IAPP transgenic islets cultured in $5.5 \mathrm{mmol} / \mathrm{l}$ glucose (Fig. 5). However, human IAPP transgenic islets cultured in $16.7 \mathrm{mmol} / 1$ glucose exhibited increased beta cell apoptosis compared with non-transgenic islets and transgenic islets cultured in $5.5 \mathrm{mmol} / \mathrm{l}$ glucose. When amyloid formation was inhibited with Congo Red, beta cell apoptosis in human IAPP transgenic islets decreased significantly compared with that in human IAPP transgenic islets cultured in $16.7 \mathrm{mmol} / \mathrm{l}$ glucose alone; it remained unchanged in non-transgenic islets and islets cultured in $5.5 \mathrm{mmol} / 1$ glucose. Interestingly, when islets were treated with the antioxidant NAC, beta cell apoptosis did not change in human IAPP transgenic islets.

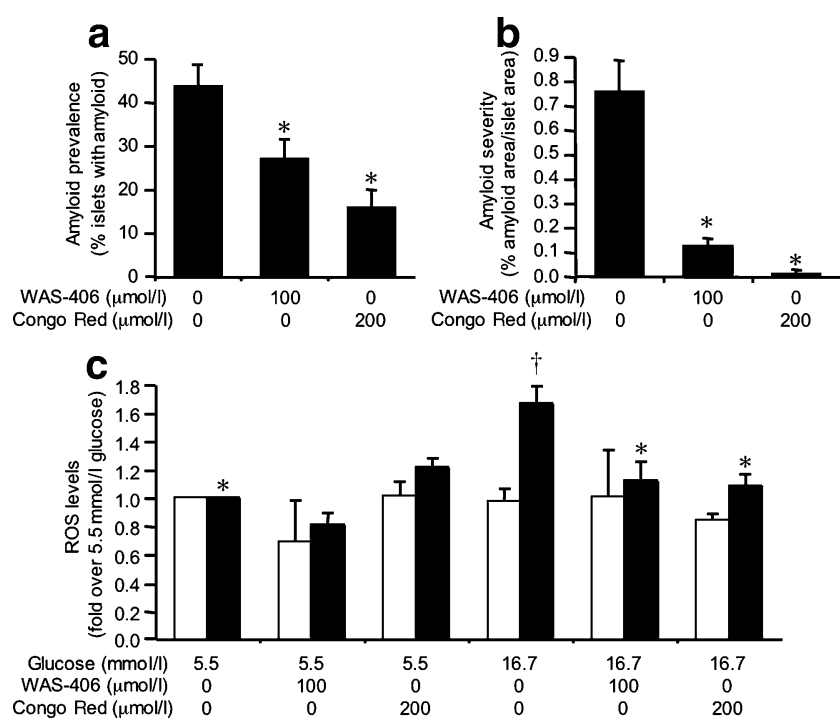

Fig. 3 Amyloid prevalence (a) and severity (b) in human IAPP transgenic islets following $48 \mathrm{~h}$ culture in $16.7 \mathrm{mmol} / \mathrm{l}$ glucose with or without the amyloid inhibitors, WAS-406 $(100 \mu \mathrm{mol} / \mathrm{l})$ or Congo Red $(200 \mu \mathrm{mol} / \mathrm{l})$. Both inhibitors significantly decreased amyloid prevalence and severity, compared with culture in $16.7 \mathrm{mmol} / 1$ glucose alone. $n=4-5 ; * p<0.05$ vs $16.7 \mathrm{mmol} / 1$ glucose. c ROS levels in nontransgenic (white bars) and human IAPP transgenic (black bars) islets following $48 \mathrm{~h}$ culture in $5.5 \mathrm{mmol} / 1$ or $16.7 \mathrm{mmol} / 1$ glucose, with or without WAS-406 or Congo Red. Data are expressed relative to the fluorescence from $5.5 \mathrm{mmol} / 1$ glucose-cultured islets. Inhibition of amyloid with WAS-406 and Congo Red significantly decreased ROS levels in human IAPP transgenic islets cultured in $16.7 \mathrm{mmol} / 1$ glucose. $n=4 ;{ }^{*} p<0.05$ vs transgenic $16.7 \mathrm{mmol} / 1 ;{ }^{\dagger} p<0.05$ vs non-transgenic 
a
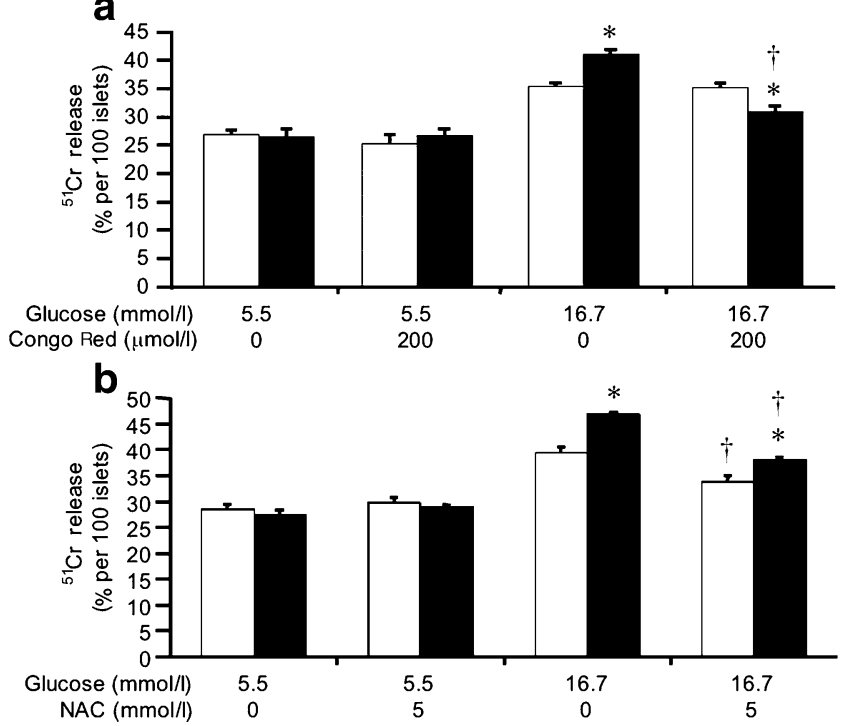

Fig. $4{ }^{51} \mathrm{Cr}$ release from non-transgenic (white bars) and human IAPP transgenic (black bars) islets after $48 \mathrm{~h}$ culture in 5.5 or $16.7 \mathrm{mmol} / \mathrm{l}$ glucose with or without (a) $200 \mu \mathrm{mol} / \mathrm{l}$ Congo Red or (b) $5 \mathrm{mmol} / \mathrm{l}$ NAC. Human IAPP transgenic islets cultured in $16.7 \mathrm{mmol} / 1$ glucose showed lowest viability, i.e. greatest ${ }^{51} \mathrm{Cr}$ release. The amyloid inhibitor, Congo Red, prevented this increased ${ }^{51} \mathrm{Cr}$ release, while having no effect on non-transgenic islets at either glucose concentration or on human IAPP transgenic islets cultured in $5.5 \mathrm{mmol} / \mathrm{l}$ glucose. The antioxidant, NAC, also reduced ${ }^{51} \mathrm{Cr}$ release in non-transgenic and human IAPP transgenic islets cultured in $16.7 \mathrm{mmol} / 1$ glucose, but had no effect in $5.5 \mathrm{mmol} / 1$ glucose. $n=4 ;{ }^{*} p<0.02$ vs non-transgenic; ${ }^{\dagger} p<$ $0.0005 \mathrm{vs}$ transgenic $16.7 \mathrm{mmol} / \mathrm{l}$

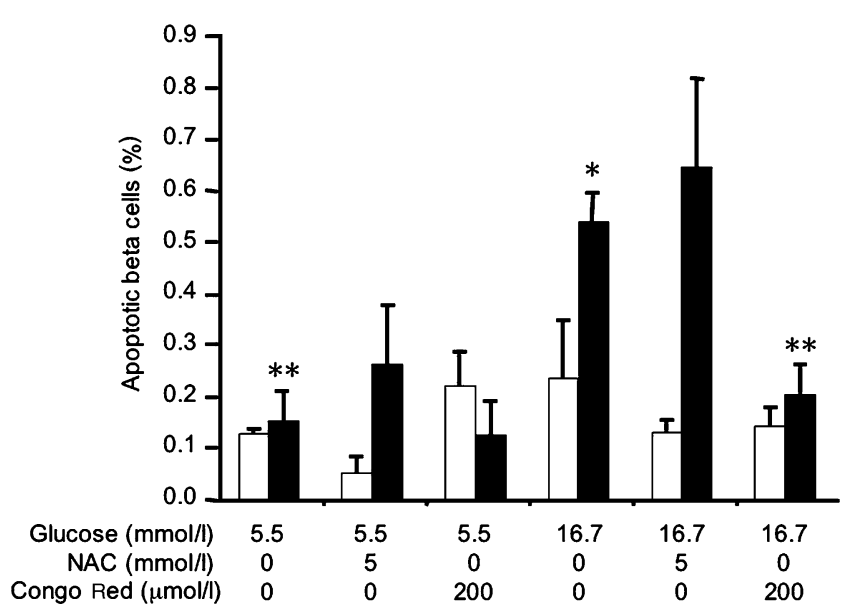

Fig. 5 Beta cell apoptosis in non-transgenic (white bars) and human IAPP transgenic (black bars) islets after $48 \mathrm{~h}$ culture in 5.5 or $16.7 \mathrm{mmol} / \mathrm{l}$ glucose, with or without $200 \mu \mathrm{mol} / \mathrm{l}$ Congo Red or $5 \mathrm{mmol} / \mathrm{l}$ NAC. Only human IAPP transgenic islets cultured in $16.7 \mathrm{mmol} / 1$ glucose showed increased beta cell apoptosis that could be reduced by co-culture with the amyloid inhibitor, Congo Red. The antioxidant, NAC, failed to reduce beta cell apoptosis in human IAPP transgenic islets cultured in $16.7 \mathrm{mmol} / 1$ glucose. $n=3-5 ;{ }^{*} p<0.05$ vs non-transgenic: $* * p<0.01$ vs transgenic $16.7 \mathrm{mmol} / 1$
Insulin secretion, content and mRNA expression after $48 \mathrm{~h}$ culture To determine whether amyloid-induced oxidative stress alters beta cell function, insulin secretion was measured after $48 \mathrm{~h}$ culture in 5.5 or $16.7 \mathrm{mmol} / 1$ glucose. Neither basal (response to $1.67 \mathrm{mmol} / \mathrm{l}$ glucose) nor glucose-stimulated (response to $16.7 \mathrm{mmol} / \mathrm{l}$ glucose) insulin secretion differed between genotypes (Fig. 6a). Islets cultured in $16.7 \mathrm{mmol} / 1$ glucose exhibited an enhanced insulin response to stimulatory glucose compared with islets in $5.5 \mathrm{mmol} / 1$ glucose, regardless of genotype (Fig. 6a). Total insulin content (Fig. 6b) and insulin mRNA expression (Fig. 6c) were not different amongst culture conditions or between genotypes.

Effect of NAC or Congo Red treatment during prolonged $16.7 \mathrm{mmol} / \mathrm{l}$ glucose culture As culture of human IAPP transgenic islets in $16.7 \mathrm{mmol} / \mathrm{l}$ glucose results in a timedependent increase in amyloid deposition [10], we investigated the relationship between amyloid and oxidative stress during prolonged culture. Islet amyloid and ROS levels were determined in non-transgenic and human IAPP transgenic islets cultured for $144 \mathrm{~h}$ in $16.7 \mathrm{mmol} / 1$ glucose with or without NAC or Congo Red. Human IAPP transgenic islets had a 1.9-fold increase in ROS levels compared with non-transgenic islets (Fig. 7a), this increase being associated with an amyloid prevalence of $52.7 \pm 9.2 \%$ (Fig. 7b) and severity of $1.81 \pm 0.23 \%$ (Fig. 7c). Nontransgenic islets did not contain amyloid.


Fig. 6 a Insulin secretion in response to $1.67 \mathrm{mmol} / 1$ and $16.7 \mathrm{mmol} / \mathrm{l}$ glucose from non-transgenic (white symbols) and human IAPP transgenic (black symbols) islets after $48 \mathrm{~h}$ culture in $5.5 \mathrm{mmol} / \mathrm{l}$ (squares) or $16.7 \mathrm{mmol} / \mathrm{l}$ (triangles) glucose. b Islet insulin content and (c) insulin mRNA expression from islets as above. White bars, nontransgenic islets; black bars, transgenic islets. There were no differences in insulin secretion, content or mRNA expression between nontransgenic and human IAPP transgenic islets after either $5.5 \mathrm{mmol} / \mathrm{l}$ or $16.7 \mathrm{mmol} / \mathrm{l}$ glucose culture. $n=4-5$. NT, non-transgenic 
In human IAPP transgenic islets, NAC significantly decreased ROS levels (Fig. 7a) and interestingly also prevented the increase of amyloid severity (Fig. 7c). As anticipated, Congo Red treatment significantly decreased amyloid prevalence (Fig. 7b) and severity (Fig. 7c), while also preventing the increase of ROS levels, in human IAPP transgenic islets; it had no effect in non-transgenic islets (Fig. 7a)

Human IAPP transgenic islets cultured in $16.7 \mathrm{mmol} / \mathrm{l}$ glucose for $144 \mathrm{~h}$ had elevated rates of beta cell apoptosis compared with non-transgenic islets (Fig. 7d). When cocultured with either NAC or Congo Red, beta cell apoptosis was reduced by 56 and $83 \%$ respectively.

To investigate whether increased amyloid formation, ROS levels and beta cell apoptosis were associated with impaired beta cell function after $144 \mathrm{~h}$ of culture, insulin secretion and content were measured. Neither basal (nontransgenic $14.8 \pm 4.8$ vs transgenic $11.7 \pm 2.3 \mathrm{pmol} \mathrm{min}^{-1}$ $\left.[100 \text { islets }]^{-1}, p=0.58, n=4\right)$ nor glucose-stimulated insulin secretion (non-transgenic $105.4 \pm 16.3$ vs transgenic $107.2 \pm$ 11.7 pmol $\left.\min ^{-1}[100 \text { islets }]^{-1}, p=0.93, n=4\right)$ differed between genotypes. Compared with that in non-transgenic islets, total insulin content was significantly reduced in human IAPP transgenic islets cultured in $16.7 \mathrm{mmol} / 1$ glucose (Fig. 7e). Co-culture of human IAPP transgenic islets with NAC tended to increase insulin content, whereas Congo Red completely restored insulin content to levels seen in non-transgenic islets (Fig. 7e).

\section{Discussion}

The current study provides evidence for a causative role of amyloidogenesis in the induction of oxidative stress in human IAPP transgenic mouse islets. It also demonstrates that in the short term amyloid-induced beta cell apoptosis is independent of oxidative stress, while in the long term, oxidative stress may feed back to exacerbate amyloid formation, thus contributing to beta cell apoptosis. In addition, we have shown that oxidative stress, islet viability, beta cell apoptosis and insulin content can be markedly improved by inhibition of amyloid formation. While this is not the first report to reveal a link between islet amyloid formation and oxidative stress, it is the first to show causality using a model that is particularly relevant to islet amyloid formation in humans, in as far as the amyloid deposits in this model form from endogenous human IAPP and are histologically comparable to the classical light microscopy-visible deposits observed in human type 2 diabetes [8].

The association between amyloid fibril formation and oxidative stress has been extensively investigated in Alzheimer's disease [42], but has not been pursued with the same intensity for islet amyloid. A limited number of studies using immortalised beta cell lines have demonstrated an elevation of oxidative stress markers upon exogenous application of human IAPP [24-26]. Further, examination of amyloid-positive islets obtained at autopsy from Japa-



Fig. 7 a ROS levels, $\mathbf{b}$ amyloid prevalence, $\mathbf{c}$ amyloid severity, $\mathbf{d}$ beta cell apoptosis and $\mathbf{e}$ insulin content in non-transgenic (white bars) and human IAPP transgenic (black bars) islets following $144 \mathrm{~h}$ culture in $16.7 \mathrm{mmol} / 1$ glucose, with or without NAC or Congo Red. ROS data are expressed relative to the fluorescence from $16.7 \mathrm{mmol} / 1$ glucosecultured non-transgenic islets. Human IAPP transgenic islets cultured in $16.7 \mathrm{mmol} / \mathrm{l}$ glucose developed amyloid and when compared with
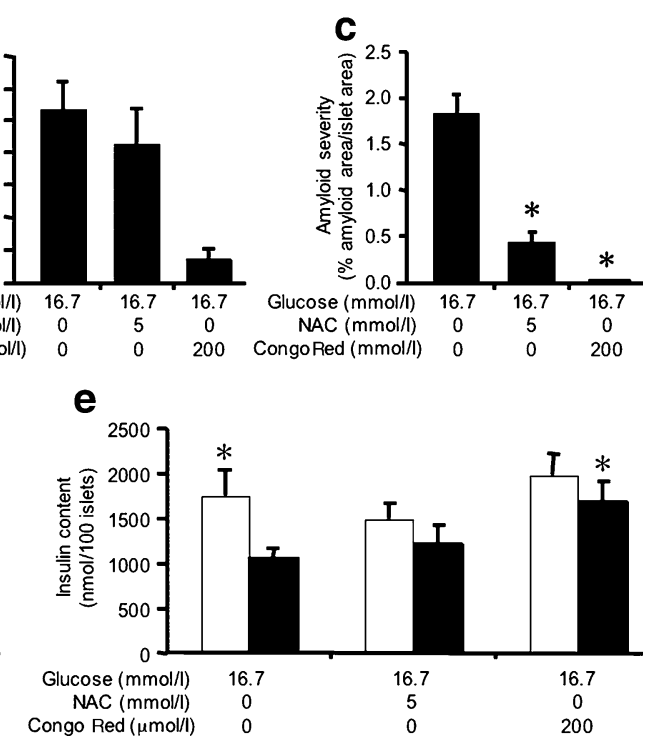

non-transgenic islets, had significantly elevated ROS levels, accompanied by increased beta cell apoptosis and reduced insulin content. NAC or Congo Red treatment of human IAPP transgenic islets reduced ROS levels, amyloid deposition and beta cell apoptosis. In addition, Congo Red significantly increased insulin content in human IAPP transgenic islets compared with non-transgenic islets. $n=4-5$; $* p<0.05$ vs transgenic $16.7 \mathrm{mmol} / \mathrm{l}$. NT, non-transgenic 
nese patients with type 2 diabetes has also revealed increased oxidative stress [23]. In our study, we demonstrate increased markers of oxidative stress in the islets of human IAPP transgenic mice, both in vivo after a year of high-fat feeding and in vitro when islets from human IAPP transgenic mice are exposed to $16.7 \mathrm{mmol} / \mathrm{l}$ glucose. As amyloid forms in vitro under conditions of elevated glucose, i.e. $16.7 \mathrm{mmol} / \mathrm{l}$, but not $5.5 \mathrm{mmol} / \mathrm{l}$ glucose [10], the lack of elevated ROS levels in human IAPP transgenic islets immediately following isolation and recovery, or after culture in $5.5 \mathrm{mmol} / \mathrm{l}$ glucose, indicates that production of amyloidogenic human IAPP as such is not sufficient to induce oxidative stress. Additionally, nontransgenic islets (incapable of forming amyloid) did not exhibit elevated ROS levels when cultured in $16.7 \mathrm{mmol} / 1$ glucose. Thus, together these observations suggest that amyloid formation in islets induces oxidative stress independently of any effects of elevated glucose.

To investigate this possibility, and in particular the causality, we used the antioxidant NAC, which has been shown to protect islets from oxidative stress in vitro and in vivo [43-45]. While we did see a marked reduction of ROS levels at $48 \mathrm{~h}$ of NAC treatment in all islets, regardless of genotype or media glucose concentration, NAC did not prevent or reduce the formation of amyloid in human IAPP transgenic islets cultured in $16.7 \mathrm{mmol} / \mathrm{l}$ glucose. This is consistent with a report on human IAPP-treated RINm5F cells [24] and strongly supports the notion that, in the short term, amyloid formation occurs prior to the increase of ROS levels. Further evidence for this hypothesis was provided by measurement of ROS levels following inhibition of islet amyloid formation with the amyloid inhibitors Congo Red and WAS-406. Both compounds markedly inhibited islet amyloid formation, consistent with previous reports [32-34]. Interestingly, treatment of human IAPP transgenic islets with either of the amyloid inhibitors also abolished the increase in ROS levels, consistent with the idea that amyloid deposition plays a causative role in induction of oxidative stress.

While detrimental effects of elevated ROS levels on the beta cell are well documented [22], involvement of oxidative stress in the toxicity of islet amyloid remains controversial. In a cell line derived from rat brain tumours, exogenous human IAPP treatment resulted in increased hydrogen peroxide levels and decreased cell viability that could be prevented with the antioxidant vitamin E [27]. In a similar study using primary rat islets, human IAPP-induced toxicity could not be prevented with vitamin E [11]; however ROS levels were not measured and so it is unclear whether the experimental conditions were associated with oxidative stress. In our study, human IAPP transgenic islets that developed amyloid and elevated ROS levels after culture in $16.7 \mathrm{mmol} / \mathrm{l}$ glucose had decreased cell viability and increased beta cell apoptosis. Inhibition of amyloid formation with Congo Red, improved cell viability and reduced beta cell apoptosis. However, $48 \mathrm{~h}$ of NAC treatment did not reduce beta cell apoptosis. This implies that, initially, amyloid-induced beta cell apoptosis occurs independently of oxidative stress. In contrast, $144 \mathrm{~h}$ of NAC treatment resulted in reductions in both amyloid severity and beta cell apoptosis. Thus it appears that over time, amyloidinduced oxidative stress potentiates further amyloid formation and thereby contributes to beta cell apoptosis. A model describing this time-dependent paradigm is shown in Fig. 8.

Non-transgenic islets cultured in $16.7 \mathrm{mmol} / \mathrm{l}$ glucose were less viable (measured as increased ${ }^{51} \mathrm{Cr}$ release) than islets cultured in $5.5 \mathrm{mmol} / \mathrm{l}$ glucose. This observation was probably due to a glucotoxic effect mediated by $48 \mathrm{~h}$ exposure to $16.7 \mathrm{mmol} / 1$ glucose and not ascribable to oxidative stress since non-transgenic islets cultured in $16.7 \mathrm{mmol} / \mathrm{l}$ glucose did not exhibit the same elevation in ROS levels as the human IAPP transgenic islets. This nonamyloid-related glucotoxicity was also seen in human IAPP transgenic islets cultured in $16.7 \mathrm{mmol} / \mathrm{l}$ glucose, as even when the amyloid-associated increase in ROS levels was inhibited, the islets were still significantly less viable than transgenic or non-transgenic islets cultured at $5.5 \mathrm{mmol} / \mathrm{l}$ glucose. These findings indicate additive cytotoxic effects of amyloid formation and glucose.

While oxidative stress due to amyloid formation was seen in human IAPP transgenic islets after $48 \mathrm{~h}$ culture, no changes in insulin secretion, content or mRNA levels were observed. This is somewhat surprising given the extensive literature describing decreased insulin secretion and suppressed insulin mRNA levels following prolonged eleva-
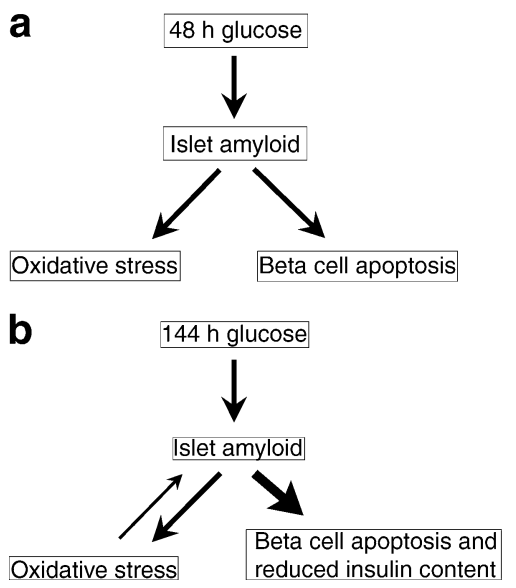

Fig. 8 a Short- and (b) long-term consequences of islet amyloid formation. Culture of human IAPP transgenic islets in $16.7 \mathrm{mmol} / \mathrm{l}$ glucose induced amyloid formation. In the short term $(48 \mathrm{~h})(\mathbf{a})$, amyloid formation induced oxidative stress and beta cell apoptosis via independent mechanisms. In the long term (144 h) (b), amyloidinduced oxidative stress fed back to potentiate amyloid formation, thereby mediating amyloid-induced beta cell apoptosis 
tions of ROS. The reason for the discrepancy between our data and other published data is unclear. However, the most likely explanation is the relatively short period of high glucose exposure. Consistent with this idea, the longer $144 \mathrm{~h}$ culture of human IAPP transgenic islets in $16.7 \mathrm{mmol} / \mathrm{l}$ glucose did result in reduced insulin content compared with non-transgenic islets, both in the present and in our previous study [10]. However, insulin secretion in response to stimulatory glucose was not decreased after either culture period. Thus, the $48 \mathrm{~h}$ and perhaps even the $144 \mathrm{~h}$ period used in the current study may be insufficient to produce measurable beta cell dysfunction, even though ROS levels and beta cell apoptosis are elevated. Another possible explanation for the difference between our data and other published data is the genetic background of the mice in our study, i.e. C57BL/ $6 \times \mathrm{DBA} / 2 \mathrm{~J} \mathrm{~F} 1$. The DBA $/ 2$ strain is genetically susceptible to high glucose-induced oxidative stress and impaired insulin secretion, whereas the C57BL/6 strain is resistant [45, 46]. Therefore, some genetic component(s) from the C57BL/6 parental strain may have protected the F1 human IAPP transgenic islets from impaired insulin secretion despite amyloid-induced ROS production. The fact that non-transgenic islets cultured in $16.7 \mathrm{mmol} / \mathrm{l}$ glucose did not exhibit elevated ROS levels is consistent with the concept of protective mechanisms against glucose-induced elevations in ROS levels. Moreover, this lack of a ROS response to $16.7 \mathrm{mmol} / \mathrm{l}$ glucose culture is an advantage of our in vitro model, as it enables the clear separation of amyloid-induced vs glucose-induced effects.

In summary, we have shown that amyloid formation induces oxidative stress in human IAPP transgenic islets, as well as decreased cell viability, increased beta cell apoptosis and reduced insulin content, but no change in insulin secretory function. In addition, prolonged oxidative stress may potentiate islet amyloid formation and its toxic effects. Given that type 2 diabetes is a progressive disorder, continuous amyloid formation and prolonged amyloidassociated oxidative stress would present a detrimental state for the beta cell. Interventions aimed at reducing and/ or preventing the formation of amyloid could prove valuable for beta cell preservation in type 2 diabetes.

Acknowledgements We thank B. Barrow, R. Bhatti, T. Braddock, M. Cone, M. Peters, J. Teague, M. Watts and J. Willard for excellent technical support. This work was supported by research funding from the Department of Veterans Affairs and NIH grants DK-75998 and DK-17047. S. Zraika was supported by a Juvenile Diabetes Research Foundation Postdoctoral Fellowship and an American Diabetes Association Mentor-Based Fellowship. R. L. Hull was supported by NIH grant DK-74404. Preparation and development of WAS-406 was funded by the Canadian Institutes for Health Research grant MOP3153, the Natural Sciences and Engineering Research Council of Canada and the Institute for the Study of Aging.

Duality of interest The authors declare that there is no duality of interest associated with this manuscript.

\section{References}

1. Westermark P, Wernstedt C, Wilander E, Hayden DW, O'Brien TD, Johnson KH (1987) Amyloid fibrils in human insulinoma and islets of Langerhans of the diabetic cat are derived from a neuropeptide-like protein also present in normal islet cells. Proc Natl Acad Sci USA 84:3881-3885

2. Cooper GJ, Willis AC, Clark A, Turner RC, Sim RB, Reid KB (1987) Purification and characterization of a peptide from amyloid-rich pancreases of type 2 diabetic patients. Proc Natl Acad Sci USA 84:8628-8632

3. Betsholtz C, Christmansson L, Engstrom U et al (1989) Sequence divergence in a specific region of islet amyloid polypeptide (IAPP) explains differences in islet amyloid formation between species. FEBS Lett 251:261-264

4. Betsholtz C, Svensson V, Rorsman F et al (1989) Islet amyloid polypeptide (IAPP):cDNA cloning and identification of an amyloidogenic region associated with the species-specific occurrence of age-related diabetes mellitus. Exp Cell Res 183:484-493

5. Westermark P, Engstrom U, Johnson KH, Westermark GT, Betsholtz C (1990) Islet amyloid polypeptide: pinpointing amino acid residues linked to amyloid fibril formation. Proc Natl Acad Sci USA 87:5036-5040

6. Opie E (1901) The relation of diabetes mellitus to lesions of the pancreas: hyaline degeneration of the islets of Langerhans. J Exp Med 5:527-540

7. Westermark P (1994) Amyloid and polypeptide hormones: what is their relationship. Amyloid Int J Exp Clin Invest 1:47-60

8. Verchere CB, D'Alessio DA, Palmiter RD et al (1996) Islet amyloid formation associated with hyperglycemia in transgenic mice with pancreatic beta cell expression of human islet amyloid polypeptide. Proc Natl Acad Sci USA 93:3492-3496

9. Hull RL, Andrikopoulos S, Verchere CB et al (2003) Increased dietary fat promotes islet amyloid formation and beta-cell secretory dysfunction in a transgenic mouse model of islet amyloid. Diabetes 52:372-379

10. Zraika S, Hull RL, Udayasankar J et al (2007) Glucose- and timedependence of islet amyloid formation in vitro. Biochem Biophys Res Commun 354:234-239

11. Lorenzo A, Razzaboni B, Weir GC, Yankner BA (1994) Pancreatic islet cell toxicity of amylin associated with type-2 diabetes mellitus. Nature 368:756-760

12. Mirzabekov TA, Lin MC, Kagan BL (1996) Pore formation by the cytotoxic islet amyloid peptide amylin. J Biol Chem 271:19881992

13. Janson J, Ashley RH, Harrison D, McIntyre S, Butler PC (1999) The mechanism of islet amyloid polypeptide toxicity is membrane disruption by intermediate-sized toxic amyloid particles. Diabetes 48:491-498

14. Bai JZ, Saafi EL, Zhang S, Cooper GJ (1999) Role of $\mathrm{Ca}^{2+}$ in apoptosis evoked by human amylin in pancreatic islet beta-cells. Biochem J 343:53-61

15. Anguiano M, Nowak RJ, Lansbury PT Jr (2002) Protofibrillar islet amyloid polypeptide permeabilizes synthetic vesicles by a pore-like mechanism that may be relevant to type II diabetes. Biochemistry 41:11338-11343

16. Janson J, Soeller WC, Roche PC et al (1996) Spontaneous diabetes mellitus in transgenic mice expressing human islet amyloid polypeptide. Proc Natl Acad Sci USA 93:7283-7288

17. Konarkowska B, Aitken JF, Kistler J, Zhang S, Cooper GJ (2006) The aggregation potential of human amylin determines its cytotoxicity towards islet beta-cells. Febs J 273:3614-3624

18. Meier JJ, Kayed R, Lin CY et al (2006) Inhibition of human IAPP fibril formation does not prevent beta-cell death: evidence for 
distinct actions of oligomers and fibrils of human IAPP. Am J Physiol Endocrinol Metab 291:E1317-E1324

19. Westermark P, Wilander E (1978) The influence of amyloid deposits on the islet volume in maturity onset diabetes mellitus. Diabetologia 15:417-421

20. Clark A, Wells CA, Buley ID et al (1988) Islet amyloid, increased A-cells, reduced B cells and exocrine fibrosis: quantitative changes in the pancreas in type 2 diabetes. Diabetes Res 9:151-159

21. Butler AE, Janson J, Bonner-Weir S, Ritzel R, Rizza RA, Butler PC (2003) Beta-cell deficit and increased beta-cell apoptosis in humans with type 2 diabetes. Diabetes 52:102-110

22. Robertson RP, Harmon JS (2006) Diabetes, glucose toxicity, and oxidative stress: a case of double jeopardy for the pancreatic islet beta cell. Free Radic Biol Med 41:177-184

23. Sakuraba H, Mizukami H, Yagihashi N, Wada R, Hanyu C, Yagihashi S (2002) Reduced beta-cell mass and expression of oxidative stress-related DNA damage in the islet of Japanese Type II diabetic patients. Diabetologia 45:85-96

24. Konarkowska B, Aitken JF, Kistler J, Zhang S, Cooper GJ (2005) Thiol reducing compounds prevent human amylin-evoked cytotoxicity. Febs J 272:4949-4959

25. Janciauskiene S, Ahren B (2000) Fibrillar islet amyloid polypeptide differentially affects oxidative mechanisms and lipoprotein uptake in correlation with cytotoxicity in two insulin-producing cell lines. Biochem Biophys Res Commun 267:619-625

26. Janciauskiene S, Ahren B (1998) Different sensitivity to the cytotoxic action of IAPP fibrils in two insulin-producing cell lines, HIT-T15 and RINm5F cells. Biochem Biophys Res Commun 251:888-893

27. Schubert D, Behl C, Lesley R et al (1995) Amyloid peptides are toxic via a common oxidative mechanism. Proc Natl Acad Sci USA 92:1989-1993

28. Tucker HM, Rydel RE, Wright S, Estus S (1998) Human amylin induces "apoptotic" pattern of gene expression concomitant with cortical neuronal apoptosis. J Neurochem 71:506-516

29. D'Alessio DA, Verchere CB, Kahn SE et al (1994) Pancreatic expression and secretion of human islet amyloid polypeptide in a transgenic mouse. Diabetes 43:1457-1461

30. Andrikopoulos S, Verchere CB, Terauchi Y, Kadowaki T, Kahn SE (2000) Beta-cell glucokinase deficiency and hyperglycemia are associated with reduced islet amyloid deposition in a mouse model of type 2 diabetes. Diabetes 49:2056-2062

31. Zraika S, Dunlop M, Proietto J, Andrikopoulos S (2002) The hexosamine biosynthesis pathway regulates insulin secretion via protein glycosylation in mouse islets. Arch Biochem Biophys 405:275-279

32. Hull RL, Zraika S, Udayasankar J et al (2007) Inhibition of glycosaminoglycan synthesis and protein glycosylation with
WAS-406 and azaserine result in reduced islet amyloid formation in vitro. Am J Physiol Cell Physiol 293:C1586-C1593

33. Kisilevsky R, Szarek WA, Ancsin JB et al (2004) Inhibition of amyloid $\mathrm{A}$ amyloidogenesis in vivo and in tissue culture by 4deoxy analogues of peracetylated 2-acetamido-2-deoxy-alpha- and beta-d-glucose: implications for the treatment of various amyloidoses. Am J Pathol 164:2127-2137

34. Aitken JF, Loomes KM, Konarkowska B, Cooper GJ (2003) Suppression by polycyclic compounds of the conversion of human amylin into insoluble amyloid. Biochem J 374:779-784

35. Green JD, Goldsbury C, Kistler J, Cooper GJ, Aebi U (2004) Human amylin oligomer growth and fibril elongation define two distinct phases in amyloid formation. J Biol Chem 279:12206-12212

36. Li X, Chen H, Epstein PN (2004) Metallothionein protects islets from hypoxia and extends islet graft survival by scavenging most kinds of reactive oxygen species. J Biol Chem 279:765-771

37. Scaglia L, Cahill CJ, Finegood DT, Bonner-Weir S (1997) Apoptosis participates in the remodeling of the endocrine pancreas in the neonatal rat. Endocrinology 138:1736-1741

38. Wang F, Hull RL, Vidal J, Cnop M, Kahn SE (2001) Islet amyloid develops diffusely throughout the pancreas before becoming severe and replacing endocrine cells. Diabetes 50:2514-2520

39. Zraika S, Hull RL, Udayasankar J et al (2007) Identification of the amyloid-degrading enzyme neprilysin in mouse islets and potential role in islet amyloidogenesis. Diabetes 56:304-310

40. Chen H, Li X, Epstein PN (2005) MnSOD and catalase transgenes demonstrate that protection of islets from oxidative stress does not alter cytokine toxicity. Diabetes 54:1437-1446

41. Tikellis C, Wookey PJ, Candido R, Andrikopoulos S, Thomas MC, Cooper ME (2004) Improved islet morphology after blockade of the renin-angiotensin system in the ZDF rat. Diabetes 53:989-997

42. Leuner K, Hauptmann S, Abdel-Kader R et al (2007) Mitochondrial dysfunction: the first domino in brain aging and Alzheimer's disease. Antioxid Redox Signal 9:1659-1675

43. Kaneto H, Kajimoto Y, Miyagawa J et al (1999) Beneficial effects of antioxidants in diabetes: possible protection of pancreatic betacells against glucose toxicity. Diabetes 48:2398-2406

44. Tanaka Y, Gleason CE, Tran PO, Harmon JS, Robertson RP (1999) Prevention of glucose toxicity in HIT-T15 cells and Zucker diabetic fatty rats by antioxidants. Proc Natl Acad Sci USA 96:10857-10862

45. Zraika S, Aston-Mourney K, Laybutt DR et al (2006) The influence of genetic background on the induction of oxidative stress and impaired insulin secretion in mouse islets. Diabetologia 49:1254-1263

46. Kooptiwut S, Kebede M, Zraika S et al (2005) High glucoseinduced impairment in insulin secretion is associated with reduction in islet glucokinase in a mouse model of susceptibility to islet dysfunction. J Mol Endocrinol 35:39-48 